STUDIA HISTORICA GEDANENSIA

TOM VIII (2017)

\title{
Łukasz Kołtuniak
}

(Wydział Prawa i Administracji, Uniwersytet Jagielloński)

\section{Chrześcijanie w Czechach jako mniejszość? Przyczyny i szanse zmiany sytuacji Kościołów w Republice Czeskiej}

Celem artykułu jest analiza dość powszechnie znanego w Polsce i Europie zagadnienia Czech jako kraju „ateistycznego”. Oficjalne badania wskazują na bardzo mały odsetek Czechów deklarujących nie tylko udział w niedzielnych nabożeństwach, ale także przynależność do jakiegokolwiek Kościoła. Zjawisko to przeanalizuję, próbując nakreślić zarys swego rodzaju historii relacji: Czechy (Czesi) - Kościół, począwszy od narodowego odrodzenia, które rozpoczęło się pod koniec XVIII w. Należy pamiętać o tradycji czeskiego husytyzmu i reformacji, a także o pierwotnym, zdaniem niemal wszystkich badaczy, źródle „zatrucia” tych relacji, jakim były represje polityczne wobec czeskich elit po porażce czeskich protestantów z obozem katolickim po bitwie pod Białą Górą w 1620 r. Artykuł podejmuje próbę analizy stosunku czeskiego ruchu narodowego do Kościoła i jego ewentualny wpływ na współczesną religijną indyferentność Czechów. Zostaną przedstawione także różnego rodzaju stanowiska tłumaczące ten niezwykle skomplikowany stosunek współczesnego Czecha do religii katolickiej i religii w ogóle. Czeski Kościół w XIX w. korzystał z przywilejów religii oficjalnej. Katolicyzm był ważnym elementem państwowej ideologii habsburskiej monarchii. Jednak Czesi przeważnie postrzegający monarchię jako zaborcę w podobnych kategoriach zaczynali postrzegać także Kościół. Przełożyło się to na skomplikowane relacje Kościół - państwo w okresie niepodległości w latach 1918-1939 (I i II Republika). Nie było jednak wówczas represji administracyjnych wymierzonych w organizację kościelną. Tym niemniej ideologia państwa zmierzała do uczynienia z Czechosłowacji państwa o dominacji wyznania husyckiego. Kościół represjonowany w latach okupacji po rewolucji komunistycznej (1948) padł ofiarą prześladowań, konfiskaty zakonów i podporządkowania administracyjnego państwu. Kościół odzyskał możliwość działania w pełni legalnie po 1989 r., nie odzyskał jednak charakteru masowego. Społeczeństwo pozostało zsekularyzowane i niechętne religii. 
Tematem tomu VIII „Studia Historica Gedanensia” są różne aspekty kwestii mniejszości. Niniejszy artykuł podejmuje próbę analizy filozoficzno-ideowych źródeł zjawiska specyficznej pozycji katolików jako mniejszości w Republice Czeskiej. W dzisiejszej Europie chrześcijaństwo znajduje się w dość głębokim kryzysie. Czeski przypadek jest jednak szczególny. We wszystkich prawie państwach europejskich obserwujemy agresywne ruchy sekularyzacyjne. Jednak cały czas większość społeczeństw deklaruje przynależność do któregoś z Kościołów, choć przynależność ta ma przeważenie charakter czysto formalny. W Czechach zaś po $1989 \mathrm{r}$. ujawnił się ewidentny wzrost zainteresowania sprawami religii. Zainteresowanie to nie ma jednak przełożenia na liczbowy wzrost populacji zadeklarowanych katolików w społeczeństwie, choć istnieje w Czechach sporo wspólnot, w których wierni wykazują się zaangażowaniem, a nawet budują swego rodzaju społeczeństwo obywatelskie. W dalszej części artykułu postaram się ukazać sytuację katolików czy szerzej chrześcijan we współczesnych Czechach. Wcześniej jednak zarysuję procesy, które doprowadziły do obecnej sytuacji - wręcz - dechrystianizacji.

Kościół doby józefińskiej korzystał w Czechach z pomocy państwa. Praski kardynał Dominik Duka wskazuje jednak, że jego oficjalna siła nie szła w parze z autentyczną religijnością ${ }^{1}$. W literaturze mówi się o austriackim modelu katolicyzmu. Miał to być katolicyzm urzędowy i oficjalny, niepołączony jednak z duchowym pogłębieniem wiary. Kardynał Duka właśnie w austriackim katolicyzmie i jego płytkości, a nie w represjach pobiałogórskich dopatruje się przyczyn obecnej słabości czeskiego Kościoła². Można jednak pokusić się o pewną refleksję historyczną. Jakkolwiek przedstawię nieco dalej krytyczną ocenę idei wiązania czeskiej tożsamości narodowej z ideą husytyzmu oraz reformacji, faktem jest, że przed Białą Górą religia była jedną z idée fixe czeskiej państwowości. Zaangażowanie górnych warstw narodu w ruch husycki i reformację było niezwykle silne. Do dziś stanowi jeden ze składników budujących czeską tożsamość. Duka zauważa, że przeżywaniu wizji reformy Kościoła towarzyszyła silna niechęć do katolicyzmu. W okresie taboru kardynał dopatruje się niechęci wręcz fanatycznej ${ }^{3}$. Po Białej Górze represje polityczne stanowczo przekraczały w Czechach zakres działań kontrreformacji, znany z doświadczeń innych państw europejskich. Aby należycie przeanalizować współczesny stan czeskiego katolicyzmu, należy uczciwie stwierdzić, że kontrreformacja oznaczała tu de facto zniszczenie narodu ${ }^{4}$. Między XVII a XIX stuleciem idea czeska przetrwała tylko wśród lokalnego chłopstwa - zatem nie była to idea całego narodu. Z punktu widzenia zaborcy, czyli Austrii, czeskość zdawała się zdegradowana do roli folkloru. Odrodzenie narodowe zaczęło się pod koniec wieku XVIII. Poszukiwano idée fixe

\footnotetext{
Dominik Duka, Tradice, která je výzvou (Praha: Portál, 2011), 24-25.

Ibidem.

3 Ibidem, 20-21.

4 Czeskie źródła dość zgodnie szacują spadek populacji kraju w XVII stuleciu z 4 do 1,5 miliona mieszkańców. W przypadku górnych warstw społeczeństwa doszło do niemal całkowitej zagłady.
} 
tego odrodzenia, odpowiedzi na pytanie: „nowy naród, ale jaki?”. Nie należy jednak przeceniać znaczenia niechęci do katolicyzmu: niektóre wizje formułowane w okresie odrodzenia uznawały religię katolicką za składnik czeskiej tożsamości. Taki pogląd wyrażał na przykład Karel Kramář, ideowy przeciwnik Tomáša Masaryka. Koncepcja Kramáŕa to czeski odpowiednik koncepcji polskiej narodowej demokracji. W tej wizji katolicyzm miał wiązać Czechów z ideami uniwersalistycznymi. Kramár uważał za podstawę czeskości nie ideę religijną, a narodową. Był pozytywistą, więc elementem koncepcji Masaryka, z którym najbardziej walczył, był swoisty czeski misjonaryzm, prowadzący jego zdaniem do pewnego rodzaju intelektualnej pułapki. Kramár jako pozytywista za główny cel pracy narodowej uważał odzyskanie suwerenności połączone z powrotem Czech do głównego nurtu europejskiej polityki ${ }^{5}$. Już ta pobieżna analiza zdaje się sugerować pewien związek między koncepcjami Kramářa z wizją Romana Dmowskiego. Ostatecznie I Republika została jednak całkowicie oparta na koncepcjach Masaryka - zupełnie przeciwstawnych Kramářowi, także $\mathrm{w}$ aspekcie filozoficzno-teologicznym.

Masaryk napisał w XIX stuleciu swoje sztandarowe dzieło Česká otázka, które stało się na wiele lat podstawą myślenia o miejscu narodu w świecie dla dużej grupy czeskiej inteligencji, która zdominowała życie polityczne w I Republice. Ową podstawą myślenia o miejscu narodu w świecie była dla Masaryka koncepcja religii. Polityk powiązał ściśle czeską ideę narodową z tradycją husycką oraz dorobkiem reformacji. Jego zdaniem właśnie w husytyzmie oraz reformacji idea czeska stała się ideą uniwersalną. Była to bowiem walka o nadanie religii autentycznego charakteru' Kościół katolicki wtłacza społeczeństwa w gorset sztywnych, biurokratycznych form. Tymczasem husytyzm i czeska reformacja były walką o nadanie religii charakteru osobistej relacji człowiek - Bóg. Religia miała być wyrwana z oków sztywnej tradycji i inspirować ludzkie serca.

Choć istnieje pewien obiegowy stereotyp czeskiej tradycji jako laickiej, I Republika miała być silnie oparta na wartościach religijnych. W czasie pierwszej wojny światowej Masaryk sformułował ideę, o którą walczą tak Czesi, jak i inne narody Słowiańszczyzny. Była to idea przezwyciężenia liberalnego indyferentyzmu i budowy nowej Europy opartej na połączeniu wartości religijnych i demokratycznych. Zdaniem Masaryka liberalizm w kształcie, w jakim dominował w Europie od połowy XIX w., oznaczał wyzucie demokracji z treści. Dominacja twardego pozytywizmu, jaka towarzyszyła owej liberalnej supremacji, pozbawiła demokrację zakorzenienia w wartościach. Ważniejsza była litera, sztywne formuły niż sam duch demokracji. Opierając demokrację o religię, widział Masaryk nadzieję na przywrócenie demokracji treści. Nie proponował jednak państwa wyznaniowego, a jedynie próbę budowy demokracji na fundamencie wyższych wartości.

Martina Winkler, Karel Kramár (1860-1937) (Praha: Argo, 2011), passim.

6 Tomáš Masaryk, Česká otázka. Naše nynější krize (Praha: Masarykuv Ustav AV CR, 2010), $150-185$. 
Taka demokracja miała stanowić pewnego rodzaju sposób życia, a nie - jak w liberalizmie - tylko literę. Demokratyczne ideały miały obejmować nie tylko ułożenie stosunków między organami państwa, ale także prowadzić do wszechstronnej przebudowy społeczeństwa w duchu wartości demokratycznych ${ }^{7}$.

Do dziś I Republika jest dla Czechów punktem odniesienia. W czasach, gdy w innych krajach Europy, także w Polsce, górę brały koncepcje faszyzujące, Czechosłowacja aż do 1938 r. zachowała demokratyczny charakter. Co więcej, było to państwo, w którym demokracja działała bez zarzutu. Można by nawet powiedzieć, że niejako inspirowało Europę.

Oczywiście kontrowersje budzi oparcie tamtego państwa na tradycji husyckiej. Taka podstawa państwowości była krytykowana także w samej międzywojennej Czechosłowacji. Na przykład Kramár, wspomniany oponent ideowy Masaryka, uważał husytyzm za próbę historycznego konstruktywizmu. Należy jednak pamiętać, że katolicyzm miał prawo budzić u Czechów negatywne emocje. Nasuwa się pytanie, czy bardziej przychylna Kościołowi koncepcja Kramářa stanowiła atrakcyjną alternatywę dla Masarykowej Republiki. Idee Kramářa pod wieloma względami cechowały się silnym nacjonalizmem 9 .

Dla Czechów nawet obecnie I Republika jest powodem do dumy. W czasie rewolucji 1989 r. skandowano: „Jesteśmy dziećmi Masaryka”. Dorobek tamtego państwa, mimo że poddawany krytyce, nie jest tu kością niezgody - jak w Polsce dziedzictwo II RP. Na przykład współczesny badacz Zdeněk David widzi w husytyzmie pierwowzór pluralizmu i tolerancji religijnej. David wskazuje, że Sobór Watykański II w dużym stopniu przypomniał wartości, na których się opierał tamten ruch odnowy ${ }^{10}$. Podobnie jak Masaryk, David widzi w husytyzmie czeski wkład w walkę o wolność i pluralizm.

Warto podkreślić, że w okresie Republiki, mimo promowania tradycji husyckiej, Kościół katolicki korzystał z pełni praw. Oczywiście próbowano wykorzystać niechętną Kościołowi elitę państwa do poróżnienia Czechów i katolickich w większości Słowaków. Te próby w dużym stopniu się powiodły, o czym świadczy oparcie słowackiego separatyzmu na ideach konserwatywnie katolickich. Niechętny katolicyzmowi charakter nowej państwowości był wykorzystywany jako element antyczeskiej propagandy także w Polsce.

Traktat monachijski oznaczał dla Czechosłowacji utratę faktycznej niepodległości, o której ludzie, którzy jej doświadczyli, mówią: „myśmy kochali Republikę”.

W czasie pierwszej wojny Masaryk walczył o sprawę czeską, przekonując do koncepcji stworzenia demokratycznego pasa państw Środkowej Europy jako przeciwwagi dla niemieckiej dominacji. Słowiański demokratyzm przeciwstawiał niemieckiemu ekspansjonizmowi. Tym niemniej Masaryk już wtedy zaproponował federację europejską, z czasem w takiej federacji miało znaleźć się miejsce także dla demokratycznych Niemiec.

8 Winkler, Karel, 45.

9 Ibidem, passim.

10 Zdeněk V. David, Nalezeni střední cesty (Praha: Filosofie, 2012), passim. 
W marcu 1939 r. niepodległość ta została zlikwidowana de iure. Upadek I Republiki był wstrząsem dla całego społeczeństwa. Opuszczenie przez zachodnich aliantów przesuwało sympatię Czechów ku sowieckiej Rosji. Tymczasem na Słowacji powstało faszystowskie państwo kierowane przez księży (na czele z Josefem Tiso $)^{11}$. Wszystkie te czynniki osłabiały zaufanie Czechów względem Kościoła, mimo że wielu księży aktywnie uczestniczyło w antyhitlerowskim ruchu oporu. Inna kwestia to zachowanie czeskiego Kościoła po wydarzeniach w Monachium. Znów można przywołać opinię kardynała Duki, który uważa, że Kościół „zdał wtedy egzamin" ${ }^{12}$. Jednak zdaniem wielu historyków, a także na przykład katolickiego księdza i filozofa Martina C. Putny, po Monachium Kościół „szkalował Republikę"13. Jeśli takie opinie mają potwierdzenie w historycznych faktach, to przy całej kontrowersji neohusyckiego dziedzictwa Masaryka moment na odreagowanie wydaje się wysoce niefortunny.

Państwowość III Republiki, jaka wyłoniła się z huraganu wojny, nie przetrwała trzech lat. Rozpoczął się okres komunistycznej ateizacji. Omawiając okres komunistyczny, należy przeanalizować dwie kwestie. Po pierwsze przyczyny tak łatwej komunistycznej ateizacji. Po drugie opór czeskiego społeczeństwa względem tej ateizacji i sytuację Kościoła w okresie komunizmu.

Nie da się ukryć, że względy historyczne ułatwiły komunistom ateizację. Kościół w Czechach nie uchodził tak jak w Polsce za obrońcę narodu, ale raczej za siłę, która niegdyś pogrzebała czeskie państwo. Taka opinia z pewnością pokutowała w czeskim społeczeństwie. Przede wszystkim po entuzjastycznym zaangażowaniu narodu czeskiego w dzieło reformacji katolicyzm nie zapełnił pewnej pustki, jaka powstała po porażce reformacji. Z pewnością błędem było, że czeski Kościół nie próbował swego rodzaju pojednania z ideą narodową. Słusznie wskazuje kardynał Duka, iż Kościół doby józefińskiej był Kościołem oficjalnym, pozbawionym treści. Wydaje się jednak, że kardynał bagatelizuje znaczenie wojny trzydziestoletniej, przekonując do poglądu, że kontrreformacja miała w Czechach charakter taki jak w innych krajach regionu. Kontrreformacja ustawiła się tu w opozycji do idei narodowej, więc $\mathrm{w}$ okresie odrodzenia ciężko było być jednocześnie Czechem i katolikiem. Proponowana przez Masaryka, a wcześniej Františka Palacký’ego, husycka wersja czeskiej tożsamości była jedynie poszukiwaniem treści idei narodowej. Ta idea jednoczyła czeskie elity XIX w. Niestety Kościół często trwał właśnie na pozycjach józefińskich, ustawiając się niejako w kontrze do owej idei. Nadal brakowało odpowiedzi na pytanie: „Czechy, ale jakie?”. Masaryk chciał wypełnić ideową próżnię ideą husycką, ale tak naprawdę siłą jednoczącą międzywojenne elity

11 „Parafiańska Republika” powstała we ścisłej współpracy z hitlerowskimi Niemcami, a jej kierownictwo ponosi odpowiedzialność także za Holocaust na ziemiach słowackich. Katolicyzm był swego rodzaju oficjalną ideologią tego państwa.

12 Duka, Tradice, která, 45.

13 Martin C. Putna, My poslední křest’ané (Praha: Hermann and Synove, 1994), 15-75. 
niepodległego państwa była koncepcja niepodległej Republiki. Tożsamość husycka była chyba jednak bardziej elementem idei narodowej, a nie jej treścią. Czeskie elity oficjalnie akceptowały Masarykowy przekaz o demokracji opartej na religii, choć zdaje się, iż tak naprawdę bliższy tym elitom był humanistyczny - nie religijny - sposób wypełnienia koncepcji republikańskiej ${ }^{14}$. Trzeba dodać, że prawdziwą katastrofą dla czeskiej religijności był międzywojenny „eksperyment” ze słowackim państwem faszystowskim. Oto kolejny raz w historii Czesi czuli się zdradzeni przez Kościół. Komuniści mogli zatem przedstawić siebie jako rzeczników idei narodowej.

Wielu czeskich myślicieli uważa, że komunizm był bliski czeskiej koncepcji narodowej. Komunistyczny przywódca, Klement Gottwald, powiedział: „Kościół zobaczy, że Czesi są narodem Jana Husa"15. Trzeba zwrócić uwagę na szereg czynników odróżniających czeskie i polskie doświadczenie z komunizmem. Po 1945 r. wrócił do Pragi rząd emigracyjny. Jeśli gdzieś w bloku wschodnim istniała szansa na uniknięcie komunizmu, to właśnie w Czechosłowacji. Co więcej, dokonała się tu prawdziwa rewolucja komunistyczna, $\mathrm{z}$ autentycznym poparciem społeczeństwa. Przekracza zakres tego artykułu dyskutowanie o narodowych cechach Czechów. Należy jedynie zwrócić uwagę, że aż do stłumienia praskiej wiosny przez wojska Układu Warszawskiego komunizm nie był w Czechosłowacji postrzegany w kategoriach narodowej niewoli. Nie stacjonowała tu ani jedna sowiecka jednostka. Po opadnięciu fali Gottwaldowskiego terroru (wzorowanego oczywiście na stalinowskim bezprawiu) rozpoczął się okres względnej wolności. Lata sześćdziesiąte to okres w czeskiej historiografii postrzegany niemal jako wolny, demokratyczny. Jednak, jeżeli chodzi o przyczyny zwycięstwa komunistów, nie wydaje się, by komunizm „pasował” do Czechów. Rewolucja lutego 1948 r. wynika z faktu, że Czesi czuli się zdradzeni przez Zachód i w ZSRR widzieli gwaranta niepodległości. Natomiast silne w całej Europie dążenie do reform społecznych mogło być wiązane z partią komunistyczną, gdyż przed wojną Gottwald i jego partia funkcjonowali w ramach demokracji parlamentarnej, zapewniając o demokratycznym charakterze czeskiego komunizmu. Przykładowo historyk Josef Kalvoda jest zdania, iż do sowietyzacji przyczyniła się pewna słabość III Republiki, ale przede wszystkim prezydenta Edwarda Benesza. Zdaniem Kalvody, zamiast załagodzić komunistyczne zagrożenie powrotem do humanistycznych ideałów Republiki,

14 Wybitny pisarz Karel Čapek był rozdarty nie tylko w kwestii stosunku do ZSRR, ale także Kościoła. Dostrzeganie elementów humanistycznych mieszało się u niego z krytyką wobec samej instytucji. W zbiorze przypowieści Księga apokryfów (Poznań: Wydawnictwo Zachodnie, 1978) tworzy własną, zgodną z jego postrzeganiem chrześcijaństwa interpretację Ewangelii. Na fascynacje osobą Čapka wskazuje ksiądz Tomáš Halík. Dla Halíka Čapek był swego rodzaju duchowym nauczycielem humanizmu, nawet mimo innego stosunku do Kościoła oficjalnego.

15 Gottwald powiedział tak w jednym ze swych pierwszych wystąpień. Wypowiedź można znaleźć w niemal wszystkich czeskich opracowaniach na temat komunizmu. 
tworzono państwo „ni to czechosłowackie, ni to sowieckie”" ${ }^{16}$. Kalvoda, podobnie jak Emmenuel Mandler, reprezentują nurt w historiografii Czech wiążący nieszczęście 1948 r. z Beneszem i słabością obozu republikańskiego ${ }^{17}$. Natomiast polski badacz, Marek Migalski, przypomina dominujący ciągle paradygmat, jakoby sowietyzacja była po prostu nieuniknionym następstwem geopolitycznej sytuacji, w jakiej znalazła się Europa Środkowa ${ }^{18}$. Stanowisko nieuchronności sowietyzacji było w Czechach dominujące. Nie wydaje się, by słuszna była teza o jakiejś szczególnej predyspozycji Czechów do komunizmu. W okresie międzywojennym partia komunistyczna faktycznie była dość silna, należy jednak poczynić zastrzeżenie, że prezentowała samą siebie jako ugrupowanie działające w ramach parlamentarnej demokracji. Jednocześnie inne doświadczenia historyczne, jakie wiązały Czechów i Rosjan, powodowały, że nie mogło być mowy o wiązaniu idei antykomunistycznej i antyrosyjskiej. Sam Masaryk oceniał Rosję dość ambiwalentnie ${ }^{19}$. Natomiast, mimo iż stosunek Kramara do Rosji ewoluował w okresie Republiki, był on zafascynowany tamtejszą kulturą. Cechował go jednak bardzo silny antykomunizm, który łączył z przekonaniem o „zniewoleniu Rosji przez komunistów"20.

Lata sześćdziesiąte w Czechosłowacji i późniejsze wydarzenia praskiej wiosny to próba reformy marksizmu i przywrócenia mu utraconej rzekomo treści. Czescy komuniści lat sześćdziesiątych nie chcieli zmiany systemu, tylko jego reformy. $\mathrm{Z}$ jednej strony ówczesny ruch reformatorski mógł wnieść do socjalizmu nowe, bardziej humanistyczne treści, a z drugiej - społeczną utopię i konstruktywizm. Otwarcie na chrześcijaństwo miało polegać na złagodzeniu polityki wobec Kościoła. Był jednak także wątek ideowy. Socjaliści mieli dostrzec w chrześcijaństwie wątki humanistyczne. Przez prawie cały okres komunistycznej dyktatury w Czechosłowacji dominowała prymitywna marksistowska krytyka chrześcijaństwa. Głosiła ona, że chrześcijanie zniewalają człowieka, gdyż jego szczęście w jedynie realnie istniejącym życiu podporządkowują Bogu, którego nikt nigdy nie widział i pewnie nikt nigdy nie zobaczy. Bóg chrześcijański to tak naprawdę uosobienie interesów klas panujących. Tymczasem linia odnowy lat sześćdziesiątych zmierzała do otwarcia marksizmu na humanistyczne treści zawarte w chrześcijaństwie. Zamiast filozoficznych podstaw dominacji klasy panującej chrześcijaństwo miało

16 Jan Cholinsky, „Edward Benesz lidova demokrace a moderni ceska statnost v podani soucasnych ceskych historiku", Střední Evropa Revue 138, http://www.revuestrednievropa.cz/upload/14. pdf, dostęp: 29 VI 2017.

17 Mandler porusza ten temat w książce o współczesnych czeskich prezydentach Havlu i Klausie - Emanuel Mandler, Oba moji prezidenti (Praha: Libri, 2004), 20-30.

18 Por. Marek Migalski, Koncepcja „mostu między Wschodem a Zachodem” Edwarda Benesza (Sosnowiec: Wydawnictwo Wydziału Szkoły Zarządzania i Marketingu, 2004), passim.

19 Masaryk fascynował się rosyjską duchowością, jednak uważał rosyjski system polityczny za niewarty naśladowania.

20 Winkler, Karel, 130-180. 
także zawierać bunt przeciwko niesprawiedliwości ludzkiej egzystencji oraz stanowić pierwszą próbę stworzenia spójnego, całościowego systemu filozoficznego. Jednak nie było tu mowy o uznaniu proponowanej przez tzw. postępowych katolików w Polsce wielości światopoglądów. Chrześcijaństwo niejako miało służyć marksizmowi autorefleksji. Czescy socjaliści proponowali nawet nieprzyjęcie pewnych wątków chrześcijaństwa. Nie było jednak możliwości ewolucji w kierunku humanistycznego socjalizmu pogodzonego z chrześcijaństwem, socjalizmu, jaki swego czasu proponował Emmanuel Mounier. Ateizm był dla marksisty podstawą światopoglądu - i tak miało zostać. Inaczej marksizm zaparłby się sam siebie ${ }^{21}$.

Trzeba podkreślić, że oprócz chrześcijan ogromne represje dotyczyły także elit I Republiki. Komunistyczna dyktatura miała w imię „, humanizmu socjalistycznego” zniszczyć autentyczny humanizm czasów Masaryka ${ }^{22}$. Nienawiść wobec dawnych elit była tym większa, że tej tradycji nie dało się zdyskredytować jako „reakcyjnej”, jak na przykład rządów sanacji w Polsce.

Jak reagował na represje czeski Kościół pod kątem ideowym? Należy pamiętać, że działał w zdecydowanie trudniejszych niż polski Kościół warunkach. Wypracowanie spójnego ideowego programu było bardzo utrudnione. Celem było przetrwanie, a walka z marksizmem była bezwzględna. Dlatego Sobór Watykański II, co podkreśla np. ksiądz Tomáš Halík, został przyjęty raczej jako zagrożenie ${ }^{23}$. Do takiej postawy należy odnieść się z pewnym zrozumieniem. Zaniepokojenie wszystkich Kościołów bloku wschodniego budziła polityka wschodnia Watykanu. Obawiano się niezrozumienia tzw. soborowych papieży dla problemów bloku wschodniego. Ponadto, jak zauważa Halík, wieszczono, że reformy podstaw teologii przyczynią się do niejakiego rozmycia katolicyzmu w marksistowskim morzu. Jednakże, jak już wspomniano, nie było jednolitego ideowego kształtu czeskiego Kościoła w okresie komunizmu. Był to Kościół walczący o przetrwanie, który siłą rzeczy musiał określać sam siebie przez pryzmat stosunku do marksizmu. Tym niemniej także w ramach tego Kościoła istniał podział na zwolenników ugody i walki. Również w Czechach lustracja księży stała się po 1989 r. kością niezgody.

W warunkach jednej z bardziej opresyjnych dyktatur w bloku wschodnim, podobnie jak w Polsce, doszło do zbliżenia ruchu dysydenckiego i niektórych księży. Księża podzielili się na tych, którzy podejmują walkę z reżimem i działają przeważnie nielegalnie, oraz na tolerowany Kościół oficjalny. Jednak bardzo prymitywny materializm rządzących komunistów rodził u niektórych dysydentów zainteresowanie religią. Odzwierciedleniem tej sytuacji są opisane przez Putnę

21 Vítězslav Gardavský, Bưh není zcela mrtev (Praha: Československý Spisovatel, 1997), 9-20.

22 Wielu przedwojennych intelektualistów zostało na przykład wysłanych do pracy w najcięższych kopalniach na Śląsku. Opowiada o tym znakomity film Jiř́ego Menzla, Skowronki na uwięzi (1969).

${ }_{23}$ Halík w wielu swoich publikacjach analizuje problem niedostatecznej recepcji Soboru w Czechach, szukając źródła tej sytuacji w obawie przed utratą spoistości w walce z komunizmem. Zdaniem Halíka brak powszechnej recepcji na grunt czeski Vaticanum II także po 1989 może być postrzegany jako błąd. 
duchowe poszukiwania Václava Havla ${ }^{24}$. Kościół w Czechach zaczął być postrzegany po raz pierwszy od wielu lat jako siła zniewolona w imię wartości, a nie siła zniewalająca. Stworzyło to dla czeskiego Kościoła ogromny potencjał do odzyskania wpływów duchowych, jednak po roku 1989 nie w pełni wykorzystany.

W 1989 r. komunistyczny reżim upadł także w Czechosłowacji. Spodziewano się poprawy sytuacji Kościołów i szybkiej rechrystianizacji. Sytuacja prawna Kościołów, o czym była już mowa, uległa radykalnej poprawie. Problemem był jedynie zwrot zagrabionego przez państwo majątku. Tak zwana restytucja kościelna budziła duże obawy i doszło do niej dopiero w 2013 r. Václav Klaus, architekt czeskich reform, przekonywał, że państwo nie może zwrócić majątku tylko Kościołom $^{25}$. Wobec niemożliwości zwrotu całego zagrabionego przez komunistów majątku, należy zatem zachować wstrzemięźliwość. Tym niemniej katolicy uzyskali w Czechosłowacji zupełnie nowe warunki działania. Symbolem zmian była wizyta w Pradze papieża Jana Pawła II na początku 1990 r. Jednak do oczekiwanej rechrystianizacji nie doszło. Obecnie tylko 34\% Czechów deklaruje wiarę w Boga. Praktykujących katolików jest 5\%, a praktykujących protestantów - 1\%. Katolicy wykazują się większym uczestnictwem we mszach w diecezjach Ołomuniec i Brno, natomiast na Śląsku Cieszyńskim wciąż silna jest duchowość protestancka (dominują tam osoby praktykujące $)^{26}$.

Czeski Kościół dalej nie określił jednoznacznie swojego stosunku do reform soborowych. Ścierają się w nim zarówno progresywne nurty, których twarzą niezmiennie pozostaje ksiądz Halík, jak również nurty dość mocno konserwatywne, przede wszystkim w Kościele Morawskim. Czołową postacią czeskiego Kościoła jest kardynał Duka. Jego linia zmierza do zachowania spoistości wewnętrznie podzielonego Kościoła. Kardynał jest postrzegany jako konserwatysta. Jego zdaniem, aby Kościół w Czechach odzyskał wpływ na wiernych, musi przede wszystkim być wierny własnej nauce. Dlatego Duka nie popiera radykalnie reformatorskich nurtów wewnątrz Kościoła. Jednocześnie jednak proponuje, by Kościół rozwijał działalność nie tylko duchową, ale też społeczną i charytatywną. Proces rechrystianizacji postrzega jako długofalowy i stopniowy.

Ksiądz Halík jest przeciwny oficjalnej linii Episkopatu. Jego zdaniem, aby Kościół w Czechach odzyskał wpływy, musi zrozumieć, że funkcjonuje w społeczeństwie, w którym dominującą religią jest tzw. „cosizm”. Czesi nie przynależą do katolicyzmu, ale nie są też co do zasady ateistami. Większość z nich odczuwa poczucie istnienia „jakiejś siły wyższej”. Dlatego Kościół w Czechach powinien, zdaniem Halíka, wcielić w życie koncepcję „dziedzińca pogan” Benedykta XVI. Powinien

24 Putna, Václav Havel. Duchovní portrét v rámu české kultury 20 století (Praha: Knihovna Václava Havla, 2012), passim.

25 Václav Klaus, Mezi minulostí a budoucností (Brno: Nadace Universitas Masarykiana, 1996), 174-175.

26 Dane ze spisu powszechnego z 2011. 
wyjść z otwartą ręka do ludzi poszukujących. Sęk w tym, że dla poszukujących religii Czechów tradycyjne formy duchowości są mało przekonujące. Konieczne jest zatem wyjście do społeczeństwa nie z dogmatyczną teologią, a filozofią przede wszystkim tłumaczącą problemy życiowe. Oczywiście, przy zachowaniu wierności religii chrześcijańskiej ${ }^{27}$.

Halík i Duka to czołowe w tym momencie postacie czeskiego Kościoła. Kościół ten poszukuje swojego miejsca we wciąż bardzo sekularnym społeczeństwie. Tymczasem, mimo wszystkich problemów w Czechach, odżywa zainteresowanie religią. Powrót do religii staje się popularny w kręgach liberalnej inteligencji, która odcina się od dziedzictwa komunistycznego. Komunizm jest tu postrzegany inaczej niż w Polsce, a za obcą okupację uchodzi w Czechach praktycznie tylko okres 1968-198928. Dlatego ściera się tu nurt odwołujący się do tradycji havlizmu, zdecydowanie negujący pozytywne skutki minionego reżimu, z nurtem reprezentowanym na przykład przez rządzącą partię CSSD, która komunistyczny reżim relatywizuje, podobnie jak inna partia koalicji ANO czy też sam prezydent Miloš Zeman. Mimo iż prezydent Havel nie przeszedł nigdy otwartej konwersji na katolicyzm, wątek istnienia wartości nadprzyrodzonych był w jego dziełach bardzo silny. Ksiądz Putna, autor duchowej biografii Havla, opisuje jego wewnętrzną ewolucję od ulegania wpływom ezoterycznym do bliskości, ale nie otwartej przynależności do religii chrześcijańskiej ${ }^{29}$. Obu czeskich prezydentów-filozofów (Masaryka i Havla) łączyło przekonanie o konieczności zakorzenienia demokracji w wyższych wartościach, przy czym Masaryk wartości te znajdował w teologii ruchu husyckiego. W XX w. Czesi stworzyli niezwykle ciekawą koncepcję państwa zakorzenionego w wyższych wartościach, a jednocześnie państwa pluralistycznego i świeckiego. Dzisiaj tak zwaną inteligencję havlowską spaja niejako osoba księdza Halíka, który otwarcie zaangażował się w bieżący spór polityczny, występując przeciwko prezydentowi Zemanowi. Zdaniem praskiego duchownego, Zeman neguje dorobek czeskiej rewolucji i podważa sens wartości demokratycznych. Jako duchowny Halík jest przeświadczony o głębokim związku dobrze rozumianych wartości chrześcijańskich i demokracji. Jest zaangażowany $\mathrm{w}$ dialog międzyreligijny, ale także $\mathrm{w}$ walkę z przejawami nacjonalizmu. Dla liberalnego czeskiego inteligenta taka wersja chrześcijaństwa, jaką reprezentuje ksiądz Halík, posiada z pewnością znaczną siłę przyciągania. Warto wspomnieć o istnieniu pisma „Střední Evropa Revue”, które już w czasach dysydenckich propagowało na emigracji połączenie wartości demokratycznych i chrześcijańskich jako elementów budowy nowej czeskiej tożsamości ${ }^{30}$. W poglądach czeskiej lewicy pokutuje jednak wciąż wizja katolicyzmu jako zagrożenia dla tradycyjnych czeskich wartości.

27 Halík jest za swoje poszukiwania dialogu z czeskim „cosizmem”, jak również zaangażowanie w dialog międzyreligijny obiektem częstej krytyki konserwatywnych środowisk katolickich.

28 Lata sześćdziesiąte są określane wręcz mianem „złotych lat sześćdziesiątych”.

29 Putna, Václav Havel. Duchovní, passim.

30 Pismo to ukazuje się do dziś, zob. http://www.revuestrednievropa.cz/upload/14.pdf, dostęp: 29 VI 2017. 
W atakach na Kościół celuje silna tu partia komunistyczna (KSCM), która zarzuca Kościołowi wprost zdradę w bliższej i dalszej przeszłości narodowych interesów. Co ciekawe, dwaj ostatni prezydenci (Klaus i Zeman) jednak wyróżniali się pozytywnym stosunkiem do Kościoła. Klaus, niegdyś liberał nieco niechętny wartościom chrześcijańskim, dostrzegł w tych wartościach źródło europejskiej tożsamości. Tego najbardziej obecnie znanego krytyka instytucji Unii Europejskiej łączy z Kościołem niechęć wobec wartości liberalno-lewicowych, dominujących we współczesnej Unii Europejskiej. Natomiast Zeman dostrzegł w kardynale Duce doraźnego sojusznika. I tak nie najlepsze relacje Duki i Halíka pogorszyły się w czasie kryzysu imigracyjnego. Zeman jest radykalnie przeciwny przyjmowaniu uchodźców: Duka ma stanowisko bardzo ambiwalentne, ale łączy go z Zemanem obawa islamizacji Europy.

Mimo że po 1989 r. Kościół odzyskał w Czechach normalne warunki działania, nie było możliwe uzyskanie przez niego wpływu na sprawy społeczno-polityczne. Dla czeskich elit jasne było, że ideałem, do którego odwołuje się nowa państwowość, jest demokratyczna I Republika. Havel był wręcz postrzegany jako nowy prezydent-filozof, nowy Masaryk ${ }^{31}$. Również Klaus wypowiadał się pozytywnie o dziedzictwie Masaryka. Dopiero Zeman nieco to dziedzictwo neguje ${ }^{32}$. Aksamitna rewolucja 1989 r. oznaczała pragnienie czeskiego społeczeństwa powrotu do najlepszych tradycji własnej państwowości. Kościół zyskiwał możliwość odzyskania pola działania w sferze duchowej i tę szansę zmarnował. Warto się zastanowić, dlaczego. Negatywny wpływ na sprawy czeskiego katolicyzmu miała tak zwana restytucja kościelna. O ile przez cały okres transformacji zwrot majątku Kościołowi był nierozwiązanym problemem, o tyle radykalna wersja restytucji przyjęta przez rząd silnie wierzącego Petra Nečasa poszła tak daleko, że lewica mogła po mistrzowsku wykorzystać silnie zakorzeniony antyklerykalizm do radykalnego osłabienia centroprawicowego rządu.

Jak wykazano, Kościół ma w Czechach normalne warunki do działania. Dominuje jednak postawa określana przez Halíka mianem „cosizmu”. Po przeanalizowaniu dyskursu medialnego zauważalne jest, że od pewnego czasu w stosunku do religii i Kościoła dominuje postawa życzliwego zainteresowania. Media często cytują kardynała Dukę, a ksiądz Halík stał się wręcz medialnym celebrytą. Do spraw religii podchodzi się poważnie i z szacunkiem. Temu zainteresowaniu tematyką religii nie towarzyszy jednak masowy powrót do Kościoła instytucjonalnego. Badania pokazują, że przekonaniu o istnieniu siły wyższej nie towarzyszy zaufanie do samego Kościoła. „Kocham Boga, ale nie kocham Kościoła” - to wypowiedź niezwykle często pojawiająca się w tamtejszych mediach. Restytucja kościelna, jaką w roku 2013 przeprowadził rząd zaangażowanego katolika Nečasa, obudziła stereotyp Kościoła pazernego ${ }^{33}$. Emocje

31 Putna, Václav Havel. Duchovní, passim.

32 Słynny stał się fakt oskarżenia przez Zemana Frantiska Peroutki, legendarnego dziennikarza z okresu Republiki, o słowa „Hitler to dżentelmen”. Gdy prezydent nie mógł potwierdzić autentyczności tych słów Peroutki, wyznaczył nagrodę za ich odszukanie (bez powodzenia).

${ }_{33}$ Kościół uzyskał niemal pełen zwrot zagrabionego majątku. Kontrowersje budziło uzasadnienie podniesienia podatku VAT właśnie koniecznością zwrotu majątku Kościołowi. 
antyklerykalne doszły do tak wysokiego poziomu, że niektóre partie (jak wspomniana CSSD) całą kampanię wyborczą budowały na zapowiedzi cofnięcia restytucji ${ }^{34}$.

Jak czeski Kościół mógłby przełamać tę nieufność ze strony społeczeństwa? Obserwacja czeskiego Kościoła, jaką prowadzę studiując na tamtejszym uniwersytecie oraz angażując się w tamtejsze życie kościelne, skłania mnie do poparcia koncepcji księdza Halíka. Charakter odrodzenia narodowego oraz późniejsza komunistyczna ateizacja wytworzyły w Czechach pewien wzór życia czy wręcz pewną życiową filozofię. Mimo tak niskiego wskaźnika przynależności do Kościołów, Czesi nie wykazują większego materializmu, przywiązywania mniejszej wagi do życia rodzinnego czy niższego kapitału społecznego niż inne narody. Problemem jest słabość tutejszej teologii i niezdolność do odróżnienia charakteru misji Kościoła w Czechach - kraju poszukującym - od misji w kraju takim jak Polska, gdzie religia jest bardzo silnie zakorzeniona. Wielu księży w czeskim Kościele myśli jednak o swej misji w kategorii oczywistości prawd katolickich. Przemawiają do wiernych tak, jakby odbiorcą przekazu był polski wierny - i to wierny wychowany od lat w kulturze katolickiej ${ }^{35}$. Warto jeszcze raz odwołać się do Putny, który uważa, że to właśnie wysyłanie czeskich księży na studia do Polski w okresie dyktatury komunistycznej i ich przesiąknięcie tradycyjną polską religijnością było największym błędem czeskiego Kościoła ${ }^{36}$. Jednakże dla kontrastu można podać przykład sukcesu w Czechach polskiego księdza, pracującego na Śląsku Cieszyńskim Zbigniewa Czendlika. Ksiądz ten, nie rezygnując z głoszenia zgodnej z nauką Kościoła teologii, zmienił i unowocześnił formy duszpasterskie. W Czechach stał się kimś na kształt duchownego-celebryty, co jak sam twierdzi pokazuje, że Czechów może zniechęcać do Kościoła nie chrześcijaństwo jako takie, ale archaiczne i konserwatywne formy przekazu ${ }^{37}$. Moim zdaniem, misją Kościoła powinno być wykorzystanie owej silnej w Czechach, widocznej w badaniach, świeckiej moralności i ukazanie zgodności między etyką od lat tu funkcjonującą i religią katolicką. Przekonuje mnie zatem koncepcja „dziedzińca pogan” promowana przez księdza Halíka. Sam Halík mówi o Czechach jako „narodzie Zacheuszy”38, czyli o społeczeństwie, które przygląda się Kościołowi z ciekawością, ale też nieufnością. Aby owemu Zacheuszowi podać rękę, należy wyjść z przekazem prawd religijnych w bardziej przystępnej i zrozumiałej formie.

Warto jeszcze zastanowić się, czy istnieje idea tożsamość nowej wyłonionej po 1989 r. państwowości czeskiej, a jeśli tak, to jak ta idea ma się do religii.

34 Z czasem okazało się, że są to obietnice bez pokrycia.

35 Putna, My poslední křest'ané, 81.

36 Ibidem.

37 Jana Benešovská, Kněz Zbigniew Czendlik: Žádný člověk na světě není sterilní a čistý, https:// www. novinky.cz/zena/styl/226367-knez-zbigniew-czendlik-zadny-clovek-na-svete-neni-sterilnia-cisty.html, dostęp: 29 VI 2017.

38 Tomáš Halík, Andrzej Babuchowski, Zacheuszu! Kazania na niedziele i święta (Kraków: WAM, 2006), 20-30. 
Wspominałem o niechęci twórców I Republiki do katolicyzmu. Państwowość, która odrodziła się po 1989 r. miała problem z określeniem stosunku do tego dziedzictwa. Z jednej strony przez cały okres komunistycznej Czechosłowacji wspomnienie tej pierwszej państwowości dawało Czechom wiarę w idee własnej niepodległości. Z drugiej - w koncepcji I Republiki było coś niepasującego do współczesności, coś, co sprawiało, że ta idea jakby nie mogła odrodzić się wprost. Dlatego ruch dysydencki i nowe państwo adoptowały poglądy Masaryka tylko częściowo. Havel i ruch dysydencki przejęły od swoich poprzedników wiarę w „niepolityczną politykę" i silne powiązanie polityki i moralności. Nie wrócono jednak do idei demokracji opartej na tradycji husyckiej. Zamiast tego podjęto próbę adaptacji wszystkich tradycji religijnych do tej nowej rzeczywistości. I tak na przykład utrzymano starą tradycję transmisji mszy husyckiej w państwowym radiu. Podkreślano także znaczenie katolicyzmu w dziejach czeskiej państwowości ${ }^{39}$. W oficjalnej historiografii próbowano szukać pozytywnej roli Kościoła w dziejach czeskiej państwowości. Istnieją liczące się partie, takie jak chadecka Kdu-CSL czy liberalne TOP 09, które wprost odwołują się do chrześcijaństwa.

Niniejszy artykuł wykazuje, że w Czechach jest miejsce na chrześcijaństwo. Winę za obecny stan rzeczy ponosi w dużym stopniu sam Kościół katolicki, a także Kościół husycki, który po 1989 r. również ma problem z odzyskaniem wiernych. Jednak za kardynalny błąd uważam podejmowane w Polsce próby dyskwalifikacji Czechów i narodu czeskiego jako „narodu szwejkowskiego”. Tradycja czeska od odrodzenia narodowego poprzez I Republikę po havlizm jest przesiąknięta demokratyzmem i humanizmem. Warto zacytować najbardziej znanego obecnie filozofa czeskiego, Václava Bělohradský'ego, który widzi w czeskiej tradycji opór wobec wszelkich prób narzucenia jednego sposobu myślenia, myślenia w kategoriach ideologicznych i zniewalających. Zdaniem Bělohradský'ego myślenie takie prezentował Kościół, dwudziestowieczne totalitaryzmy i po części prezentuje współczesny tzw. neoliberalizm ${ }^{40}$. Czesi nie są narodem „Szwejków”, a narodem, który tyle wycierpiał w imię swojego przywiązania do wolności, że możemy mówić o „tragedii małego wolnego narodu” ${ }^{4}$. Kościół musi więc szukać formy istnienia w ramach czeskiej państwowości, która ma swój niepowtarzalny charakter, a jeśli będzie liczył na jakiś nowy józefinizm, jest skazany na porażkę. Jednak obecność w Czechach duchownych wielkiego formatu oraz bardzo ciekawe próby symbiozy tradycji havlowskiej i chrześcijańskiej pokazują, że religia w Czechach może się odrodzić, unikając tragicznych - zarówno dla religii, jak i czeskiego narodu - błędów przeszłości.

39 Jeśli szukać dziś tradycji religijnej, wokół której jest budowana czeska państwowość, to jest to raczej tradycja św. Wacława niż husycka.

40 Václav Bělohradský, Eseje o nedávné minulosti a blíské budoucnosti (Praha: G plus G, 1999), 13-63.

41 Łukasz Kołtuniak, Tragedia małego wolnego narodu, http://www.teologiapolityczna.pl/ lukasz-koltuniak-tragedia-malego-wolnego-narodu/, dostęp: 29 VI 2017. 
Podsumowując, warto kolejny raz podkreślić spójność i pewną filozoficzną ciągłość między tradycją odrodzenia Palacký ego i Masaryka a dziedzictwem Hávla, Jana Patoczki czy Bělohradský ego. Niesłusznie wyśmiewani u nas Czesi, bardzo umiejętnie łączą trzy główne nurty, jakie kreowały europejską cywilizację: humanizm, oświecenie i chrześcijaństwo. Fatalne dziedzictwo komunizmu, zwłaszcza niszczącej dla tkanki społecznej normalizacji z okresu po praskiej wiośnie, sprawia, że nowa państwowość nie spełnia do końca oczekiwań czeskiej inteligencji. Dziś, gdy inteligencja wywodząca swe korzenie z myśli Hávla i Masaryka zamierza bronić tego dziedzictwa, Kościół i czeska inteligencja mogą znaleźć się po tej samej stronie barykady. Kościół w Czechach musi jednak przełamać swoje pewne ograniczenia. Umiejętność rozliczenia się z dziedzictwem Białej Góry i józefinizmu byłaby tu bardzo pomocna. Co więcej, duchowni nie powinni prowadzić debaty na takim poziomie, jak w okresie sporu o restytucję, gdy sami zadbali o to, by znów zarzucano im pazerność. Smutne jest to, że wielu duchownych zdaje się nie rozumieć kraju, w którym pracuje. Wychodzą z założenia, że Czechów trzeba nawrócić przez ukazanie wartości duchowych. Dla czeskiego Kościoła najważniejsze jest zrozumienie, że pracuje w kraju z silną duchową tradycją, jednak sytuującą się na granicy wspomnianych w artykule trzech prądów. Nie będzie nigdy kompromisu między chrześcijaństwem a komunistycznym ateizmem, który w Czechach przyjął szczególnie prymitywne formy. Jednakże może dojść do porozumienia między ludźmi wyznającymi chrześcijańskie wartości a zwolennikami koncepcji Hávla i Masaryka. Jeden z protestanckich duchownych powiedział, że gdyby Kościół był w okresie reformacji taki jak w czasie Vaticanum II, nigdy nie doszłoby do reformacji. To samo można by chyba powiedzieć o rozłące między czeską szlachtą i inteligencją a katolicyzmem. W demokratycznych i humanistycznych Czechach na chrześcijaństwo wciąż jest miejsce.

\section{Łukasz Kołtuniak \\ Christians as a Minority in the Czech Lands: Causes of and Opportunities for Change in the Situation of the Christian Churches in the Czech Republic}

\section{Summary}

In any discussion of Catholicism in the Czech Lands and in Poland, two stereotypes are quite widespread: "a Pole is a Catholic" and "a Czech is an atheist". However, if we look at the situation of Christianity in the Czech Republic, we see how complex the sources of the present state of affairs are, and how complicated the relationship of Czechs is to religion. Indeed, the introduction to the article emphasizes how greatly exaggerated the widely accepted stereotype of the "Czech-atheist" is. The article aims to analyze Czech religious discourse from the beginning of the national reawakening at the end of the eighteenth century, in order to answer the question as to why Christians became a minority in the Czech Lands. A further question considered is how Christians function as a minority. 